\title{
Strategy to Improve English Vocabulary Achievement during Covid-19 Epidemic. Does Quizizz Help?
}

\section{Law Szee Huei ${ }^{1}$ \\ Melor Md Yunus ${ }^{2}$ (iD Harwati Hashim ${ }^{3}$}

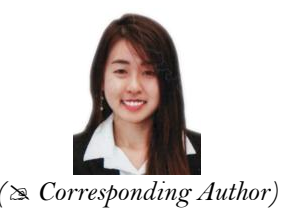

${ }^{1.2,3}$ Faculty of Education, Universiti Kebangsaan Malaysia, Malaysia. :Email:sea-huei@hotmail.mvTel:6016589076. Email:melor@ukm.edu.my Tel: 60389216277

'Email:harwati@ukm.edu.my.Tel:60196993717

\section{Abstract}

Science, Technology, Engineering, and Mathematics (STEM) education is being increasingly recognized as needing vital emphasis at a national level. To enhance learning in Science and Mathematics, the repertoire of vocabularies plays a significant role. As the coronavirus disease 2019 (COVID-19) continues its spread across the world, people's vocabulary learning has been limited. Responding to this situation with appropriate awareness, e-learning is being applied to teach the English language. The intent of this study is to utilize Quizizz to enhance the vocabulary achievement among primary English as Second Language (ESL) pupils in rural schools. The study's research employed mixed methods with purposive sampling of 13 participants. The research site was a rural school located $60 \mathrm{~km}$ from the nearest town. The data were collected both pre and post-test as designed by the researcher and Likert scale questionnaire. The data was analyzed using appropriate quantitative analysis. To shed more light on the implementation, a thematic analysis by use of a semi-structured interview was conducted. The study finds that 10 out of 13 participants have shown an increase in their post-test of filling in the blank scoring test. The data is strengthened by a moderately high mean score of a Likert scale questionnaire. Furthermore, the participants highlighted that the Quizizz's leaderboard matched their favored learning style. In this way, this feature tends to evoke a positive learning atmosphere. Thus, it can be concluded that Quizizz could enhance vocabulary achievement among primary English as Secondary Language (ESL) pupils in rural schools.

Keywords: Education, COVID-19, English vocabulary, Quizizz, E-learning, Rural School.

Citation | Law Szee Huei; Melor Md Yunus; Harwati Hashim (2021). Strategy to Improve English Vocabulary Achievement during Covid-19 Epidemic. Does Quizizz Help?. Journal of Education and e-Learning Research, 8(2): 135-142.

History:

Received: 2 December 2020

Revised: 8 January 2021

Accepted: 15 February 202

Published: 10 March 2021

Licensed: This work is licensed under a Creative Commons Attribution 3.0 License $(\mathrm{ccc}) \mathbf{E}$

Publisher: Asian Online Journal Publishing Group
Acknowledgement: All authors contributed to the conception and design of the study.

Funding: The authors received financial support from Universiti Kebangsaan Malaysia Research Grant coded MRUN-RAKAN RU-2019-003/4 and GG2019-006.

Competing Interests: The authors declare that they have no conflict of Competing

Transparency: The authors confirm that the manuscript is an honest, accurate, and transparent account of the study was reported; that no vital features of the study have been omitted; and that any discrepancies from the study as planned have been explained.

Ethical: This study follows all ethical practices during writing.

\section{Contents}

1. Introduction

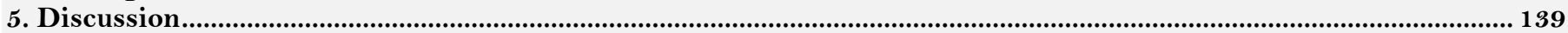

6. Conclusion

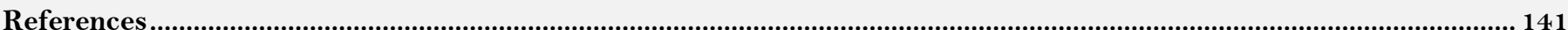




\section{Contribution of this paper to the literature}

This study is to utilize Quizizz in enhancing vocabulary achievement among primary English as Second Language (ESL) pupils in a rural school.

\section{Introduction}

The world around us is enveloped by the rapid growth of the Fourth Industrial Revolution (IR 4.0). Thus, new challenges are arising. One of the key elements of IR 4.0 is the consolidation of the knowledge of Science, Technology, Engineering, and Mathematics (STEM) into the human population (Chong, 2019). There is a widespread effort to emphasize STEM through all educational stages. In the context of IR 4.0 innovation, English is in great demand as it is an instrument that unites the disciplines of science, technology, and mathematics (Nga, Lan, \& Nam, 2018). Educators have recognized that the major obstacle for human resource managers in the hiring process is Malaysian students' lacking command of the English language. To leverage the scientific knowledge which is often conveyed in English, it is best to be taught in English (Mahmud, Nasri, Samsudin, \& Halim, 2018). A large and growing body of literature has investigated vocabulary as the foundation among all the English language learning skills. Vocabulary is reviewed as the most significant building block of language acquisition (Bai, 2018; Nie \& Zhou, 2017; Nurdiansyah, Asyid, \& Parmawati, 2019). Today, due to the pandemic caused by COVID-19, the effort of enhancing English language and vocabulary learning has been limited by the schooling dimension (Famularish, 2020; Suparsa \& Mantra, 2020).

Ali and Rosli (2019) explained that to maximize the learning outcome, it is essential to opt for a teaching delivery method that emphasizes the effectiveness of interactive learning. They further elaborated that e-learning is an interactive digital technology that contributes to increased motivation and total engagement among learners. Elearning is referred to as an innovative, web-based system that blurs the boundaries between settings by increasing the flexibility in accessing a learning experience (A. Kukulska-Hulme, Gaved, Jones, Norris, \& Peasgood, 2017). Education systems in Malaysia have highlighted that students are now in the era of globalization. Learners need to be equipped with skills related to e-learning to maximize effective learning. Thus, the Frog Virtual Learning Environment (VLE) was introduced in 2013 and served as an online learning platform.

However, Frog VLE was ended on June 30, 2019. E-learning in the lesson had contributed to cooperative skills, interactive skills, and students' learning autonomy. Besides, Elekaei, Tabrizi, and Chalak (2020) highlighted that collaborative e-learning enables knowledge sharing activity, and students could boost other learners. Nonetheless, a study placed the limitations of Frog VLE into two main categories (Zoolkafli, 2019). The first order barrier was the infrastructure, namely limited access, lack of training, and impracticality. The second-order barriers were teachers' attitudes toward technology (Ali \& Deris, 2019; Gryzelius, 2015).

Following the termination of Frog VLE, Google Classroom took over the online learning platform. It appeared Google Classroom claimed to be less user-friendly (Azhar \& Iqbal, 2018; Ballew, 2017). In contrast, several studies provided the advantages of Quizizz, such as being interactive, offering competitive (Zhao, 2019) self-assessment (Rahayu \& Purnawarman, 2019), and being user-friendly (Wibawa, Astuti, \& Pangestu, 2019). Quizizz is one of the most famous applications used to assess learners' knowledge and progress (Amalia, 2020; Suryaman, Akbar, \& Salsabila, 2020). Driven by the awareness of the need for STEM education and the potential use of technology, the researcher conducted education research with the alternative e-learning tool, Quizizz. Previous research conducted Quizizz in a non-English-based lesson. Liong, Kwan, Abdullah, Govindasamy, and Yunus (2019) and Wibawa et al. (2019) conducted Quizizz in idioms and grammar lessons. Highlighting the statement by Wibawa et al. (2019) and Mukhtar, Zainal, Nasir, and Yunus (2019), Quizizz is among the best alternative mobile applications. The integration of technology with the goal of enhancing language teaching has become an everyday occurrence. The researcher was enlightened in integrating Quizizz into vocabulary learning. The significance of this study is that it helps educators uncover the potential of Quizizz in enhancing the English language, specifically vocabulary, that many researchers had not explored. The resulting data could encourage parents to cooperate with teachers as enhancing literacy is a three-way partnership (Harji, Balakrishnan, \& Letchumanan, 2017). Thus, this study aims to investigate the relationship between Quizizz and the enhancement of primary ESL pupils' vocabulary.

\section{Literature Review}

\subsection{Theories in teaching vocabulary}

On a par with advanced multimedia applications, there are various theoretical bases for the development of effective tools in teaching vocabulary. One significant theory of vocabulary teaching in multimedia applications is the Cognitive Theory of Multimedia Learning (CTML). Kanellopoulou, Kermanidis, and Giannakoulopoulos (2019) stated that learners actively participate in constructing connections between words and pictures for longterm memory retention. Learners are effective in the aspects of selecting and organizing words with images, then integrating them with their prior knowledge. Another theory is Dual Coding Theory (Kanellopoulou et al., 2019; Moody et al., 2018). It also focuses on the connections between visual images and words, as well as taking contextual references into account. When educators are only focusing on the association of words with visual triggers, it is not Dual Coding Theory but multimodal theory. This is another theory that involves the interaction between three or more symbols to construct meaning. Specifically, the research of Boers, Warren, Grimshaw, and Siyanova-Chanturia (2017) concluded that new words are more likely to be remembered when the word meaning is illustrated visually.

\subsection{Process in vocabulary acquisition}

The path to acquiring vocabulary involves noticing, retrieving, and creatively using targeted words (Kanellopoulou et al., 2019; Moody et al., 2018). When learners encounter unfamiliar words, noticing them directs the learner to learn. Next, the more often words are retrieved, the higher the likelihood of the words embedding deeply in learners' minds (Atikah \& Rezki, 2018; Boers et al., 2017). Anggrarini (2018) reviewed the data that 40\% of vocabulary learning activity is listening and repeating so as to root the words in the learner's mind. The last 
stage, creative use, could be achieved when the learners were exposed to words after stages one and two or when the words were used differently from their previous encounter with the words.

\subsection{E-Learning in teaching English language and vocabulary from previous studies}

Today, e-learning has become more and more prevalent, especially during the COVID-19 pandemic. Among various e-learning tools, smartphones are recommended as Agnes Kukulska-Hulme et al. (2015) revealed that smartphones could support informal, authentic, and personalized learning. Different types of e-learning could be classified based on the duration of the interaction. Bezhovski and Poorani (2016) elaborated asynchronous elearning as self-paced learning. On the other hand, synchronous e-learning tools require both educators and learners to be present at the same time. Thus, the concept of vocabulary teaching through e-learning is either through the asynchronous or synchronous use of electronic tools.

The learning outcome could be maximized by leveraging the suitability of e-learning in delivering vocabulary. Andreani and Ying (2019) and Lin (2015) used PowPow and Trade Ruler to sustain learners' focus. Compliant with the subsequent research of the online vocabulary game by Alfehaid (2019), 97\% of teachers strongly agreed that online vocabulary games are beneficial in vocabulary learning. Likewise, vocabulary could be taught by conducting healthy competition among the learners (Lakshmi, 2016). A recent review (Wong \& Yunus, 2020) found that participants could learn vocabulary posted by their friends on Mentimeter. Hence, vocabulary could be acquired in a fun way through learners' study preferences (Godwin-Jones, 2014).

Recent research implemented the combination of several symbol resources in an effort to enhance vocabulary learning. Lin and $\mathrm{Wu}(2016)$ received higher post-test scores when vocabulary was learned via a video through email or Facebook. Likewise, in the study of App book by Wang, Christ, and Chiu (2018), there was 9\% of vocabulary variance. App book was noted to have the features of interactivity, hyperlinks, feasibility, and narrative or illustration. Hence, these two researchers echoed with the multimodal theory to aid vocabulary learning effortlessly.

Synchronizing with the acquisition of vocabulary, several studies focused on the repetition of words through the use of e-learning tools (Ali \& Deris, 2019; Elekaei et al., 2020; Posyidin, 2019). The Duolingo mobile quiz session enables learners to recap on their previous learning session. Audio Podcast plus's animated picture showed the experimental group had a better vocabulary gain and retention. The majority of the participants agreed Quizlet's effectiveness in learning vocabulary with its repetition of target words. Strong evidence was shown that all of the participants agreed that Televocabot's effectiveness was due to the feature of recapping the words. Recapping through repetition engaged the learners and enabled them to learn. Around $84.9 \%$ of Said et al. (2013) participants stated that blogging enabled them to check their word choices and spelling more carefully, highlighting the engagement aids the learning process. In general, students' engagement is the primary factor for successful e-learning (Jaleel, Sukri, \& Ayub, 2019).

\subsection{Challenges of using E-learning to teach the English language and vocabulary}

Despite the advantages, there are obstacles to using e-learning. The biggest challenge to not achieving the learning objective is the time constraints (Earslan \& Topkaya, 2017). Also, the response from educators argued that creating a visual space to learn vocabulary in is time-consuming and expensive (Candry, Deconinck, \& Eyckmans, 2018). In line with this, Sadikin (2016) also highlighted barriers such as individual characteristics, technical challenges, knowledge challenges, and contextual challenges. Despite the obstacles in conducting Web Quest, all the students achieved improvement in mastering vocabulary. The last challenge is identified as desynchronizing of the targeted language skill (Heil, Wu, \& Lee, 2016). The researcher argued that a picture matching application signified a lack of contextual usage in vocabulary teaching. However, this study focused on reading comprehension rather than vocabulary achievement. Moreover, there are alternative apps such as Babbel which teach vocabulary in context. Overall, there was no perfect e-learning tool. As explained earlier, e-learning for vocabulary is the encoding of vocabulary through the asynchronous or synchronous use of electronic tools. Whether asynchronous self-learning, or synchronous learning requiring knowledgeable others, a good homeschool relationship merits vocabulary learning (Harji et al., 2017).

\subsection{Quizizz in teaching the English language}

Findings and discussions from Liong et al. (2019) showed Quizizz improved the achievement scores of forty secondary school suburban learners in learning English language idioms. The flexibility of accessing Quizizz merited the learning of idioms. Moreover, Quizizz could be attempted numerous times. Thus, learners could monitor their achievement and strive to improve their current score. A broader perspective on Quizizz has been adopted by Wibawa et al. (2019). They highlighted that Quizizz could be a learning medium if it achieved five criteria, namely adequate Wi-Fi, accessed virtually anywhere, enthusiasm of learners, fair in scoring, and in accordance with students' learning preference. More recent evidence (Mohamad, Arif, Alias, \& Yunus, 2020) pointed out that marks displayed on the leaderboard in Quizizz promote a positive learning experience. Therefore, this study would like to explore the practicality of using Quizizz in rural schools.

\section{Methodology \\ 3.1. Research design}

This study implemented an action research design as it fits with the use of pre-tests and post-tests to evaluate the achievement in vocabulary. This selected design is defined as systematic, together with organized steps, which was mostly adopted in an educational setting for collecting data (Haj-Bolouri, Purao, Rossi, \& Bernhardsson, 2018). The present study applied a mixed-method approach. The difference in scores between pre-test and post-test, together with quantifying a Likert scale, served as quantitative data. At the same time, thematic analysis was derived from the semi-structured interview presented as qualitative data.

The study was conducted during a Movement Control Order (MCO) due to COVID-19. The study progressed in accordance with the Lewin and Laidlaw action research model, which involved five stages (Haj-Bolouri et al., 
2018). The researcher started to implement Quizizz in the period of a Conditional Movement Control Order (CMCO). During the third week of a Recovery Movement Control Order (RMCO), the post-test was conducted. A better description of these five steps for conducting the study is tabulated in Table 1.

Table-1. Stages of the study.

\begin{tabular}{|c|c|c|}
\hline Week & MCO Phase and remarks & Stages \\
\hline 1 & \multirow[t]{2}{*}{ MCO phase $1(18 / 3-31 / 3)$} & \multirow[t]{2}{*}{ Identifying a focus } \\
\hline 2 & & \\
\hline 3 & \multirow{2}{*}{ MCO phase $2(1 / 4-14 / 4)$} & \multirow[t]{6}{*}{ Planning } \\
\hline 4 & & \\
\hline 5 & \multirow{2}{*}{ MCO phase $3(15 / 4-28 / 4)$} & \\
\hline 6 & & \\
\hline 7 & \multirow{2}{*}{ MCO phase $4(29 / 4-12 / 5)$} & \\
\hline 8 & & \\
\hline 9 & $\mathrm{CMCO}(13 / 5-19 / 5)$ & \\
\hline 10 & CMCO (20/5-26/5) Hari Raya Aidilfitri (21/05-22/05) & $\begin{array}{l}\text { Implementation } \\
\text { Pre-test and Lesson 1:20.05.20 }\end{array}$ \\
\hline 11 & CMCO (27/5-2/6) Mid-year school holiday (25/05-05/06) & \\
\hline 12 & CMCO (3/5-9/6) Mid-year school holiday (25/05-05/06) & \\
\hline 13 & $\operatorname{RMCO}(10 / 6-16 / 6)$ & Lesson 2: 10.06 .20 \\
\hline 14 & $\operatorname{RMCO}(17 / 6-23 / 6)$ & Lesson 3: 17.06.20 \\
\hline 15 & $\mathrm{RMCO}(24 / 6-30 / 6)$ & Post-test: 26.06 .20 \\
\hline 16 & $\operatorname{RMCO}(1 / 7-7 / 7)$ & Observing \\
\hline 17 & $\operatorname{RMCO}(8 / 7-14 / 7)$ & Evaluation \\
\hline
\end{tabular}

3.2. Research participants

Two rationales drove the purposive sampling of 13 students from a year 4 class. First was the matter of accessibility of the selected pupils, sourcing people as equivalent as possible in social, cultural, economic, and academic levels. Second was the students' eagerness to take part in the study. The participants' involvement, along with their caregivers, was completely voluntary. The research site was $60 \mathrm{~km}$ away from the town, categorizing it as a rural school. Among the samples, three out of 13 pupils had A1-low and B1-low in English language proficiency, respectively. The remaining seven were A2-low. The level of proficiency is based on the school's formative assessment in congruence with the Common European Framework Reference (CEFR) as cited in Namaziandost, Nasri, and Esfahani (2019).

\subsection{Pre-test and post-test}

Pre-tests and post-tests were applied to identify the effectiveness of Quizizz in enhancing vocabulary achievement. The researcher focused on the appropriate way to present vocabulary, rebus-replacing pictures into words. This was to ensure the participants were familiar with the words they were learning in context, acquiring the face validity of the test. Moreover, reference books were also used. Before implementing pre-tests and posttests, a pilot test was administered on a random sample of six pupils who shared similar characteristics in terms of academic, social, cultural, economic, and academic levels with the samples. The test was also validated by experts. The reliability was first enhanced through a difficulty coefficient. The test consisted of both high- and lowfrequency sight words. Next, the test was enhanced with a discrimination coefficient. To differentiate between the high and low achievers, some of the sentences were adapted into complex sentences.

\subsection{Likert Scale questionnaire}

The questionnaire was constructed by adapting it from previous studies (Atmazaki \& Indriyani, 2019; Cheng, 2020; Wang, 2017). The researcher implemented the (Behling \& Law, 2000) technique. Three translators with excellent proficiency in both English and the Malay language were appointed. The first translator translated the Likert scale questionnaire from English into Malay. Next, the second translator back translated it from Malay into English. Then, the third translator compared the original and back translated versions and prepared the final draft. Based on the recommendation from these experts, and also taking into account participants' comprehension levels, the Likert scale questionnaire was constructed. Through reviewing previous studies and the feedback from the experts, each scale and item in the questionnaire were closely related as a group.

\subsection{Semi-structured interview}

The semi-structured interviews aimed to gain an in-depth description of how Quizizz helps participants to learn vocabulary. The study of Lau (2019), which utilized Frog VLE in vocabulary learning, served as the reference for constructing interview questions. The questions were revised through the back translation method described above with English and Malay language experts. Changes were made so as to suit local settings and participants' understanding.

\subsection{Data analysis procedure}

The result from filling in the blank scoring test is tabulated in the table below for both pre- and post-tests. The researcher recorded the increment in the percentage of the result, and the differences are tabulated. From the result, the CEFR level was also compared. In triangulating data, the Likert Scale questionnaire was also utilized. The questionnaire data are tabulated and presented in the form of percentages so as to answer the research question. At the same time, a back translation of the transcripts of semi-structured interviews was conducted with the experts (Behling \& Law, 2000). 


\section{Findings}

In general, Quizizz showed an improvement in vocabulary achievement. Table 2 presents the data from filling in the blanks scoring test. The first column indicates the pre-tests and is followed by the post-test scores. The last column shows the comparison viewpoint between the tests. Table 2 shows ten participants improved, whereby the biggest percentage was 50\% (S2). One participant's score (S8) decreased, 10\%. Two participants (S12 and S13) showed no significant relationship between Quizizz and vocabulary achievement. In the pre-test, five participants $(\mathrm{S} 1, \mathrm{~S} 2, \mathrm{~S} 3, \mathrm{~S} 4$, and $\mathrm{S} 5)$ obtained a score of $30 \%$, and one participant $(\mathrm{S} 6)$ obtained $40 \%$. What is striking in Table 2 is that the six participants who were initially A1 achievement reduced to only one participant. Besides, two of the low vocabulary achievement learners $\left(\mathrm{S}_{2}=30 \%\right.$ and $\left.\mathrm{S} 6=40 \%\right)$ enhanced their levels, from basic learner to independent learner with $80 \%$, respectively. Three participants (S8, S12, and S13) claimed that their performances were influenced by inconducive test orientation and anxiety. In the pre-test, the highest level was B1-low. In contrast, five participants surpassed B1-low in the post-test. Overall, having five fewer A1 levels and five more advanced B1 signified the participants had gained a significant level of vocabulary knowledge.

\begin{tabular}{c|c|c|c|c|c}
\hline \multicolumn{7}{c}{ Table-2. Comparison between pre-test and post-test. } & Difference (\%) \\
\hline Sample & Pre-test (\%) & CEFR level & Post-test (\%) & CEFR level & +40 \\
\hline S1 & 30 & A1-low & 70 & B1-low & +50 \\
\hline S2 & 30 & A1-low & 80 & B1-low-medium & +20 \\
\hline S3 & 30 & A1-low & 50 & A2-low & +30 \\
\hline S4 & 30 & A1-low & 60 & A2-high & +10 \\
\hline S5 & 30 & A1-low & 40 & A1-low & +40 \\
\hline S6 & 40 & A1-low & 80 & B1-low-medium & +10 \\
\hline S7 & 50 & A2-low & 60 & A2-high & -10 \\
\hline S8 & 60 & A2-high & 40 & B1-medium high & +20 \\
\hline S9 & 70 & B1-low & 90 & B1-low-medium & +10 \\
\hline S10 & 70 & B1-low & 80 & B1-low-medium & +10 \\
\hline S11 & 70 & B1-low & 80 & B1-low & - \\
\hline S12 & 70 & B1-low & 70 & B1-low & - \\
\hline S13 & 70 & B1-low & 70 & &
\end{tabular}

Apart from filling in the blanks scoring test, five Likert Scale questionnaires were utilized. The items which achieved the most percentage were statements 1,3 , and 6 . These three statements are attained by $62 \%$ of the participants, respectively, $n=8$. These three statements showed that the participants were more engaged, had more learning opportunities, and had better vocabulary mastery. As can be observed from Table 3, all the statements are highly rated on a scale of 4, agree. Thus, the overall mean score for the questionnaire was 3.9. Based on the interpretation by Ibrahim, Bakar, Asimiran, Mohamed, and Zakaria (2015), the score is signified as moderately high.

Table-3. Self-assessment on vocabulary achievement.

\begin{tabular}{|c|c|c|c|c|c|c|c|}
\hline No. & Statements & $\begin{array}{c}\text { Strongly } \\
\text { disagree } \\
(1)\end{array}$ & $\begin{array}{l}\text { Disagree } \\
\quad(2)\end{array}$ & $\begin{array}{c}\text { Don't } \\
\text { know } \\
(3) \\
\end{array}$ & $\begin{array}{c}\text { Agree } \\
(4)\end{array}$ & $\begin{array}{c}\text { Strongly } \\
\text { agree } \\
(5)\end{array}$ & $\begin{array}{l}\text { Mean } \\
\text { score }\end{array}$ \\
\hline 1 & $\begin{array}{l}\text { I am more focusing on the lesson once the } \\
\text { teacher using Quizizz. }\end{array}$ & $\begin{array}{c}0 \\
(0 \%)\end{array}$ & $\begin{array}{c}0 \\
(0 \%)\end{array}$ & $\begin{array}{c}1 \\
(8 \%)\end{array}$ & $\begin{array}{c}8 \\
(62 \%) \\
\end{array}$ & $\begin{array}{c}4 \\
(30 \%) \\
\end{array}$ & 4.2 \\
\hline 2 & $\begin{array}{l}\text { I memorize the vocabulary faster once I } \\
\text { play Quizizz. }\end{array}$ & $\begin{array}{c}0 \\
(0 \%)\end{array}$ & $\begin{array}{c}1 \\
(8 \%)\end{array}$ & $\begin{array}{c}4 \\
(30 \%)\end{array}$ & $\begin{array}{c}5 \\
(39 \%)\end{array}$ & $\begin{array}{c}3 \\
(23 \%)\end{array}$ & 3.8 \\
\hline 3 & $\begin{array}{l}\text { I have more opportunities to learn English } \\
\text { by using Quizizz. }\end{array}$ & $\begin{array}{c}0 \\
(0 \%)\end{array}$ & $\begin{array}{c}1 \\
(8 \%) \\
\end{array}$ & $\begin{array}{c}2 \\
(15 \%) \\
\end{array}$ & $\begin{array}{c}8 \\
(62 \%)\end{array}$ & $\begin{array}{c}2 \\
(15 \%) \\
\end{array}$ & 3.8 \\
\hline 4 & $\begin{array}{l}\text { Quizizz feedback for questions makes me } \\
\text { focus. }\end{array}$ & $\begin{array}{c}0 \\
(0 \%)\end{array}$ & $\begin{array}{c}2 \\
(15 \%)\end{array}$ & $\begin{array}{c}3 \\
(23 \%)\end{array}$ & $\begin{array}{c}5 \\
(39 \%)\end{array}$ & $\begin{array}{c}3 \\
(23 \%)\end{array}$ & 3.7 \\
\hline 5 & $\begin{array}{l}\text { Quizizz helps me to collaborate with others } \\
\text { (my classmates and family members). }\end{array}$ & $\begin{array}{c}0 \\
(0 \%)\end{array}$ & $\begin{array}{c}1 \\
(8 \%)\end{array}$ & $\begin{array}{c}4 \\
(30 \%)\end{array}$ & $\begin{array}{c}5 \\
(39 \%)\end{array}$ & $\begin{array}{c}3 \\
(23 \%)\end{array}$ & 3.8 \\
\hline 6 & $\begin{array}{l}\text { Quizizz is an effective tool to help me } \\
\text { master vocabulary. }\end{array}$ & $\begin{array}{c}0 \\
(0 \%)\end{array}$ & $\begin{array}{c}0 \\
(0 \%)\end{array}$ & $\begin{array}{c}4 \\
(30 \%)\end{array}$ & $\begin{array}{c}8 \\
(62 \%)\end{array}$ & $\begin{array}{c}1 \\
(8 \%)\end{array}$ & 3.8 \\
\hline \multicolumn{7}{|c|}{ Overall mean score } & 3.9 \\
\hline
\end{tabular}

A total of 13 participants were invited for the follow-up semi-structured interview. The selected excerpts and the frequency of each sub-theme that had been mentioned are tabulated. At the end, the excerpts are attached with a $[\# \mathrm{n}]$. What can be seen in Table 4 is the three main themes, which are the factors that encouraged interviewees to learn vocabulary involuntary. Preferable vocabulary learning strategy was the most significant factor, specifically multi-featured learning strategies as mentioned most frequently by the interviewees. This could be identified when the second participant claimed that everything in Quizizz is in her favor. The feature was also mentioned by the fourth participants, who asserted that learning is only a click with the fingertip. Another participant then elaborated, in detail, that it was the pictures that engaged him to learn vocabulary.

\section{Discussion}

Being aware of the transformations brought about by IR 4.0, Liong et al. (2019) conducted learning English idioms through Quizizz. In compliance with previous research, this study investigates the effectiveness of Quizizz in enhancing the vocabulary learning of rural school pupils. The findings from filling in the blanks scoring test showed the increment of marks to be a minimum of $10 \%$ to a maximum of $50 \%$. Apart from this, nine out of the 13 participants advanced their initial CEFR level. The present result of $77 \%$ pupils in marks increment is even higher than the previous result conducted by Liong et al. (2019) at 63\%. This further exemplifies the success of Quizizz in learning the English language, especially in vocabulary achievement. Moreover, the response of seven participants 
also correlates fairly well with Mohamad et al. (2020) and further supports the role of the leaderboard in facilitating academic learning taking place.

Table-4. Selected excerpts from the semi-structured interview.

\begin{tabular}{|c|c|c|}
\hline Theme & Sub-theme & Excerpts \\
\hline \multirow[t]{2}{*}{$\begin{array}{l}\text { Perceived } \\
\text { usefulness }\end{array}$} & $\begin{array}{l}\text { Usefulness } \\
\text { motivating } \\
\text { (mentioned by four } \\
\text { interviewees) }\end{array}$ & $\begin{array}{l}\text { "Quizizz is useful. It helps me to stay motivate." [Student\#1] } \\
\text { "It is useful because I see I learn more. I want to copy new words." } \\
\text { [Student\#7] } \\
\text { "My previous learning method is boring, this (Quizizz) is different. I } \\
\text { have desire to learn. }[\text { Student\#13] }\end{array}$ \\
\hline & $\begin{array}{l}\text { Usefulness } \\
\text { engaging } \\
\text { (mentioned by six } \\
\text { interviewees) }\end{array}$ & $\begin{array}{l}\text { "I am engaging to the lesson. I can play for many times." [Student\#4] } \\
\text { "Quizizz is a game. Game, I want play more games. Play more question." } \\
\text { [Student\#6] } \\
\text { "It makes me focus to learn. I am not sleepy." [Student\#8] }\end{array}$ \\
\hline \multirow[t]{2}{*}{$\begin{array}{l}\text { Preferable } \\
\text { vocabulary } \\
\text { learning } \\
\text { strategy }\end{array}$} & $\begin{array}{l}\text { Multi-features } \\
\text { learning strategy } \\
\text { (mentioned by ten } \\
\text { interviewees) }\end{array}$ & $\begin{array}{l}\text { "I like all about Quizizz. I like everything." [Student\#2 }] \\
\text { "I like the answering session the most because it's only choosing the } \\
\text { answer." [Student\#4] } \\
\text { "I can see the pictures. I can see the cartoon pictures and real pictures." } \\
\text { [Student\#7] }\end{array}$ \\
\hline & $\begin{array}{l}\text { Learning through } \\
\text { competition } \\
\text { (mentioned by three } \\
\text { interviewees) }\end{array}$ & $\begin{array}{l}\text { "The last part to see my name. I want to be the first. If not the first, I } \\
\text { want to be the top } 3 \text {. If not top } 3 \text {, at least top } 5 \text {. [Student\#7] } \\
\text { "I am not always the last. I correct more and faster, my name over the } \\
\text { others" [Student\#9] }\end{array}$ \\
\hline $\begin{array}{l}\text { Evoke } \\
\text { learning } \\
\text { emotion }\end{array}$ & $\begin{array}{l}\text { Positive learning } \\
\text { emotion } \\
\text { (mentioned by nine } \\
\text { interviewees) }\end{array}$ & $\begin{array}{l}\text { "Quizizz is fun and exciting to answer faster than my friends." } \\
\text { "Student\#3] } \\
\text { "Happy to see my name. Happy to keep playing. Many times, I can play." } \\
\text { [Student\#9] }\end{array}$ \\
\hline
\end{tabular}

Based on the moderately high mean score of participants' self-assessing vocabulary achievement, the practicality of Quizizz in vocabulary learning is justified. The present research finding was anticipated and consistent with previous studies that highlighted that E-learning promotes immersion and enhances vocabulary learning. This is also supported by Alfehaid (2019), who highlighted online vocabulary games increase learners' success and are beneficial to vocabulary learning. This is further cemented by the researchers' participants. Almost all of the participants agreed that Quizizz created an immersive learning environment. They recognized Quizizz has the characteristics of collaborating, providing feedback, and offering a learning opportunity. Hence, the research discovered that Quizizz is a preferred learning strategy for learners (Godwin-Jones, 2014). This preference plays a significant role as supported by the cognitive theory of multimedia learning, stating learners tend to have higher memory retention when they can connect words with pictures (Kanellopoulou et al., 2019).

During the interview session, the outcomes also confirmed the beneficial use of Quizizz in widening the repertoire of vocabulary. One interviewee said, "I can see the pictures. I can see the cartoon pictures and real pictures." Turning now to the basics of vocabulary teaching, Moody et al. (2018) suggested visualizing the word of vocabulary in its correct context. Quizizz fulfilled the theory of Dual Coding vocabulary teaching. Quizizz displayed both pictures and words simultaneously in a sentence, instead of just providing a wordlist with pictures. This multi-symbol approach aids learners in constructing meaning, as concluded by Boers et al. (2017). Interestingly, Quizizz, which was initially oriented for assessment, could be leveraged to teach vocabulary. These findings are also supported by Elekaei et al. (2020), who claimed the feature of visual and verbal annotation in their article. Thus, Quizizz aids vocabulary learning through the multimodal theory.

However, one out of the 13 interviewees claimed she preferred to have face-to-face learning rather than use Quizizz. She appeared to be a little unresponsive when the researcher mentioned the final leaderboard of Quizizz. This was probably the result of psychosocial development and industry vs. inferiority. Gaming with a competition element is not everyone's cup of tea, as described as gender preference by Godwin-Jones (2014). Another insight was when two of the interviewees highlighted “...to see my name." This was another interesting feature of elearning. Another study in line with the current study was Barham (2017). His participants rated eight or nine points out of ten, claiming that e-learning was fun, simple to use, and autonomous. When learners have fun, they have the desire to learn. These findings are consistent with an earlier study by Lakshmi (2016). She utilized Power Vocabulary, a mobile application, as it creates healthy competition among learners. This current study seems to align with the research of Wibawa et al. (2019) and Mukhtar et al. (2019), who both claimed that Quizizz is the best gamified-learning application, especially for vocabulary learning. Therefore, for e-learning, Quizizz could enhance vocabulary achievement as it boosts learners' interest through engagement.

\section{Conclusion}

With information at the tips of our fingers, learning is now limitless. Vocabulary learning is essential as it is an essential foundation of developing language skills. Promoting a high repertoire of the English language could benefit pupils for STEM education, as English bridges the knowledge to the learners across the globe. Before planning STEM education, educators might need to draw their attention to a strategy for English vocabulary teaching during the COVID-19 pandemic. The finding from this study confirms the association between Quizizz and vocabulary achievement. The explanations for this result are that Quizizz is equipped with the vocabulary theory of marginal effect, and it is multimodal. Providing an immersive learning environment through recapping words is another explanation for the good correlation between Quizizz and vocabulary learning. This study produced results that corroborate the findings of a great deal of the previous work in the field of e-learning. Previous researches acknowledged the usefulness of e-learning but highlighted the lack of practicality in terms of the time it takes. However, Quizizz is not limited to a timeframe. The educators could set the duration for each 
word, ranging from five seconds to 15 minutes. Learners could complete the learning in a more flexible timeframe ranging from hours up to 14 days.

A longitudinal study is recommended in the future to further justify the effectiveness of Quizizz in enhancing vocabulary achievement. This study only implemented multiple choice in the teaching of vocabulary. To teach vocabulary, educators could include other options such as fill-in-the-blank and open-ended as offered by the webpage. Consequently, educators are urged to take this study to another stage. By doing so, the use of e-learning could provide help to a range of ESL teachers and learners to improve both the teaching and learning experiences.

\section{References}

Alfehaid, A. (2019). Online English language learning activities and academic achievement: Experiences of first-year students and their teachers. Pertanika Journal of Social Sciences and Humanities, 27(3), 1557-1572.

Ali, N. H., \& Rosli, R. A. H. M. (2019). Digital technology: E-content development using Apple technology. Malaysian Journal of Distance Education, 21(1), 83-94.Available at: https://doi.org/10.21315/mjde2019.21.1.5.

Ali, A. S. M., \& Deris, F. D. (2019). Vocabulary learning through Duolingo mobile application: Teacher acceptance, preferred application features and problems. International Journal of Recent Technology and Engineering, 8(2S9), 79-85.Available at: 10.35940/ijrte.B1017.0982S919.

Amalia, D. F. (2020). Quizizz website as an online assessment for English teaching and learning: Students' perspectives. Journal of English Language Teaching Fakultas, 7(1), 1-8.Available at: https://doi.org/10.33394/jo-elt.v7i1.2638.

Andreani, W., \& Ying, Y. (2019). Powpow interactive game in supporting English vocabulary learning for elementary students. Procedia Computer Science, 157, 473-478.Available at: https://doi.org/10.1016/j.procs.2019.09.005.

Anggrarini, N. (2018). Activities in teaching English vocabulary. English Journal of Indragiri, 2(2), 30-42.Available at: https://doi.org/10.32520/eji.v2i2.235.

Atikah, D., \& Rezki, A. (2018). Repetition facilitates retrieval opportunity in vocabulary learning. IOP Conference Series. Earth and Environmental Science, 175(1), 1-7.Available at: 10.1088/1755-1315/175/1/012148.

Atmazaki, \& Indriyani, V. (2019). Digital literacy competencies for teacher education students. Advances in Social Science, Education and Humanities Research, 335, 1010-1018.Available at: https://doi.org/10.2991/icesshum-19.2019.156.

Azhar, K. A., \& Iqbal, N. (2018). Effectiveness of Google classroom: Teachers' perceptions. Prizren Social Science Journal, 2(2), 52-66.

Bai, Z. (2018). An analysis of English vocabulary learning strategies. Journal of Language Teaching and Research, 9(4), 853-859.Available at: http://dx.doi.org/10.17507/jltr.0904.24.

Ballew, T. (2017). Teacher perceptions of a technology-based google classroom. Doctoral Dissertation., Carson-Newman University, United States.

Barham, K. (2017). The use of electronic dictionary in the language classroom: The views of language learners. Paper presented at the Annual Meeting for the Society of the Second International Conference for Learning and Teaching in the Digital World/ Smart Learning, Palestine.

Behling, O., \& Law, K. S. (2000). Translating questionnaires and other research instruments: Problems and solutions. Thousand Oaks, CA: Sage.

Bezhovski, Z., \& Poorani, S. (2016). The evolution of e-learning and new trends. International Institute for Science, Technology and Education, $6(3), 50-57$.

Boers, F., Warren, P., Grimshaw, G., \& Siyanova-Chanturia, A. (2017). On the benefits of multimodal annotations for vocabulary uptake from reading. Computer Assisted Language Learning, 30(7), 709-725.Available at: https://doi.org/10.1080/09588221.2017.1356335.

Candry, S., Deconinck, J., \& Eyckmans, J. (2018). Written repetition vs. oral repetition: Which is more conducive to L2 vocabulary learning? Journal of the European Second Language Association, 2(1), 72-82.Available at: http://doi.org/10.22599/jesla.44.

Cheng, C.-C. (2020). Game-based learning and TOEIC vocabulary building: NNES student s' learning attitudes and motivations. Journal of Applied Linguistics and Language Research, 7(1), 135-143.

Chong, C. J. (2019). Preliminary review on preparations in Malaysia to improve STEM education. Journal of Sustainability Science and Management, 14(5), 135-147.

Earslan, A., \& Topkaya, E. Z. (2017). EFL students' attitudes towards e-learning and effect of an online course on students' success in English. The Literacy Trek, 3(2), 80-101.

Elekaei, A., Tabrizi, H. H., \& Chalak, A. (2020). Evaluating learners' vocabulary gain and retention in an e-learning context using vocabulary podcasting tasks: A case study. Turkish Online Journal of Distance Education, 21(2), 190-203.Available at: https://doi.org/10.17718/tojde.728162.

Famularish, S. (2020). Students' experiences in using online learning applications due to COVID-19 in English classroom. Studies in Learning and Teaching, 1(2), 112-121.Available at: https://doi.org/10.1080/21532974.2010.10784651.

Godwin-Jones, R. (2014). Games in language learning: Opportunities and challenges. Language Learning and Technology, $18(2)$, 9-19.

Gryzelius, J. (2015). ICT in classroom learning: Exploring the discrepancies between ideal conditions and current Malaysian policy IDEAS institute for democracy and economic affairs. Retrieved from http://ideas.org.my/wp-content/uploads/2017/03/PI-no-18-ICT-inClassroom-Education.pdf.

Haj-Bolouri, A., Purao, S., Rossi, M., \& Bernhardsson, L. (2018). Action design research in practice: Lessons and concerns. Paper presented at the Proceedings at AIS Electronic Library.

Harji, M. B., Balakrishnan, K., \& Letchumanan, K. (2017). The PaCT: Parents, children and teacher partnership in developing ESL literacy. English Language Teaching, 10(9), 150-160.Available at: https://doi.org/10.5539/elt.v 10n9p150.

Heil, C. R., Wu, J. S., \& Lee, J. L. (2016). A review of mobile language learning applications: Trends, challenges and opportunities Catherine. European Association for Computer-Assisted Language Learning, 24(2), 32-50.Available at: 10.4995/eurocall.2016.6402.

Ibrahim, W. N. A., Bakar, A. R., Asimiran, S., Mohamed, S., \& Zakaria, N. S. (2015). Impact of entrepreneurship education on the entrepreneurial intentions of students in technical and vocational education and training institutions (TVET) In Malaysia. International Education Studies, 8(12), 141-156.Available at: 10.5539/ies.v8n12p141.

Jaleel, H. B. A., Sukri, W. L. N. W. O., \& Ayub, E. (2019). Transforming teaching and learning paradigm to empower 21 st century learners: Participatory Online Course (POC) for Hubungan Etnik module at Taylor's University, Malaysia. International Journal of Education, $4(30), 265-282$.

Kanellopoulou, C., Kermanidis, K. L., \& Giannakoulopoulos, A. (2019). The dual-coding and multimedia learning theories: Film subtitles as a vocabulary teaching tool. Education Science, 9(210), 1-13.Available at: https://doi.org/10.3390/educsci9030210.

Kukulska-Hulme, A., Gaved, M., Jones, A., Norris, L., \& Peasgood, A. (2017). Mobile language learning experiences for migrants beyond the classroom. The Open Univerisity, 219-224.Available at: 10.1515/9783110477498-030.

Kukulska-Hulme, A., Gaved, M., Paletta, L., Scanlon, E., Jones, A., \& Brasher, A. (2015). Mobile incidental learning to support the inclusion of recent immigrants. Ubiquitous Learning: An International Journal, 7(2), 9-21.Available at: https://doi.org/10.18848/18359795/cgp/v07io2/58070.

Lakshmi, G. V. S. A. (2016). Mobile apps: A powerful tool for vocabulary development. International Journal of English: Literature, Language and Skills, 5(2), 142-148.

Lau, J. C. L. (2019). Virtual learning environment: Effectiveness in enhancing teaching of vocabulary to secondary ESL learners. Doctoral Dissertation, UTAR.

Lin, H. (2015). Effectiveness of interactivity in a web-based simulation game on foreign language vocabulary learning. Procedia - Social and Behavioral Sciences, 182, 313-317.Available at: https://doi.org/10.1016/j.sbspro.2015.04.772.

Lin, C. M., \& Wu, C. (2016). Idea sharing: Do students learn better through a more entertaining way? The case of Taiwan EFL students. PASAA: Journal of Language Teaching and Learning in Thailand, 51, 269-280.

Liong, Y., Kwan, P., Abdullah, A. N., Govindasamy, P., \& Yunus, M. M. (2019). Learn idioms the fun and mobile way with Quizizz. International Journal of Scientific and Technology Research, 8(12), 1749-1752. 
Mahmud, S. N. D., Nasri, N. M., Samsudin, M. A., \& Halim, L. (2018). Science teacher education in Malaysia: Challenges and way forward. Asia-Pacific Science Education, 4(1), 1-12.Available at: https://doi.org/10.1186/s41029-018-0026-3.

Mohamad, M., Arif, F. K. M., Alias, B. S., \& Yunus, M. M. (2020). Online game based formative assessment: Distant learners post graduate students' challenges towards Quizizz. International Journal of Scientific and Technology Research, 9(4), 994-1000.

Moody, S., Hu, X., Kuo, L. J., Jouhar, M., Xu, Z., \& Lee, S. (2018). Vocabulary instruction: A critical analysis of theories, research, and practice. Education Science, 8(180), 1-22.Available at: https://doi.org/10.3390/educsci8040180.

Mukhtar, N. H., Zainal, N., Nasir, N. A. M., \& Yunus, M. M. (2019). QLETZ: Noun-you-know online module for vocabulary learning. International Journal of Scientific and Technology Research, 8(12), 2777-2781.

Namaziandost, E., Nasri, M., \& Esfahani, F. R. (2019). Texts with various levels of hardness, reading comprehension and reading motivation. Journal of English Language Teaching Fakultas, 8(1), 60-77.

Nga, H. T., Lan, T. T., \& Nam, N. H. (2018). Teaching English for 5th grade student in primary school via Science topics on approach of STEM education: A case study of learning outside school activities. HNUE Journal of Science, 63(9), 61-69.Available at: 10.18173/2354-1075.2018-0169.

Nie, Y., \& Zhou, L. (2017). A study of vocabulary learning strategies used by excellent English learners. Research on Modern Higher Education, 4, 101-106.

Nurdiansyah, D. M. R., Asyid, S. A., \& Parmawati, A. (2019). Using color coding to improve students' English vocabulary ability. Professional Journal of English Education, 2(3), 358-363.Available at: https://doi.org/10.22460/project.v2i3.p358-363.

Posyidin, M. (2019). Televocabot: An interactive vocabulary learning source for college student of English language education department. Journal of English Language Teaching Learning and Literature, 3(1), 1-14.

Rahayu, I. S. D., \& Purnawarman, P. (2019). The use of quizizz in improving students' grammar understanding through self-assessment. Paper presented at the Eleventh Conference on Applied Linguistics (CONAPLIN 2018). Atlantis Press.

Sadikin, I. S. (2016). The use of WebQuest for teaching English vocabulary in an EFL young learners' context. International Conference on Transportation and Traffic Engineering, 1(1), 403-410.

Said, N. E. M., Yunus, M., Doring, L. K., Asmi, A., Aqilah, F., \& Li, L. K. S. (2013). Blogging to enhance writing skills: A survey of students' perception and attitude. Asian Social Science, 9(16), 95-101.Available at: https://doi.org/10.5539/ass.v9n 16p95.

Suparsa, I. N., \& Mantra, I. B. N. (2020). Covid-19 terminologies: The extent of student's vocabulary acquisition during learning from home. International Journal of Linguistics and Discourse Analytics, 2(1), 41-47.

Suryaman, M., Akbar, F., \& Salsabila, S. (2020). English education students as pre-service English teachers' perception on Quizizz: Considering mall utilization as a pedagogical tool. Indonesia Technology Enhanced Language Learning, 139-142.Available at: https://doi.org/10.1080/08934215.2014.9627523.

Wang, X. C., Christ, T., \& Chiu, M. M. (2018). Exploring the relationship between kindergarteners' buddy reading and individual comprehension of multimodal digital texts. Paper presented at the Proceedings of the 15th International Conference on Cognition and Exploratory Learning in the Digital Age CELDA 2018.

Wang, B. T. (2017). Designing mobile apps for English vocabulary learning. International Journal of Information and Education Technology, 7(4), 279-283.Available at: https://doi.org/10.18178/ijiet.2017.7.4.881.

Wibawa, R. P., Astuti, R. I., \& Pangestu, B. A. (2019). Smartphone-based application “Quizizz" as a learning media. Education Dynamics, 14(2), 244-253.Available at: 10.15294/dp.v 14i2.23359.

Wong, P. M., \& Yunus, M. M. (2020). Enhancing writing vocabulary using Mentimeter. International Journal of Learning, Teaching and Educational Research, 19(3), 106-122.Available at: https://doi.org/10.26803/ijlter.19.3.7.

Zhao, F. (2019). Using Quizizz to integrate fun multiplayer activity in the accounting classroom. International Journal of Higher Education, 8(1), 37-43.Available at: https://doi.org/10.5430/ijhe.v8n1p37.

Zoolkafli, F. A. (2019). What is Frog VLE and what are the issues or challenges of Frog VLE integration in Malaysia classrooms. Journal of Leadership Reflection, 2, 53-69. 